\title{
LONGITUDINAL MULTIPLE RELATIONS OF PHYSICAL EDUCATION PARTICIPATION, SCHOOL GRADE, AGE, AND SEX WITH CARDIORESPIRATORY FITNESS CHANGES IN CHILDREN: A MEDIATOR ROLE OF CHANGES IN BODY COMPOSITION
}

\author{
Vanilson Batista Lemes ${ }^{1 *} \&$ Rodrigo Baptista Moreira ${ }^{2}$
}

\begin{abstract}
LEMES, V.B; MOREIRA, R. B. Longitudinal multiple relations of physical education participation, school grade, age, and sex with cardiorespiratory fitness changes in children: A mediator role of changes in body composition. Perspectivas Online: Biológicas \& Saúde, v.11 , n.39 , p. $37-57,2021$.
\end{abstract}

To verify the multiple relations of physical education participation, school grade, age, and sex with longitudinal cardiorespiratory fitness changes in children and to identify if there is a mediator role of longitudinal body composition changes in these relations. Methodology: This is a longitudinal study, carried out from March to November of 2019, with children from 6 to 12 years old, 150 boys and 80 girls. Children were classified according to a cut point of $70 \%$ of participation in physical education classes $(>70 \%=$ High PE $x<70 \%=$ Low PE). Outcomes were Body Composition (BC): body mass index, skinfolds, waist to height ratio, and Cardiorespiratory fitness (CRF). Individual delta variation $(\Delta \%)$, Cohens $D$, Bonferroni test, generalized estimative equations (GEE), and structural equations model (SEM) were estimated. Results: The results show a general boy's and girl's increasing in $\mathrm{BC}$ variables and a decrease in $\mathrm{CRF}$ at follow-up which more strength in the Low PE group compared to the High PE group. The SEM model showed that Children in the High PE group have the most decrease in $\mathrm{BC}$ variables and it is a role to relations between the High PE group with increasing in CRF. Conclusions: High PE group was associated with a $\triangle \% \mathrm{CRF}$ increase, it is an indirect association mediated by $\Delta \% \mathrm{BC}$ reduction. The SEM presents children that reduce $\mathrm{BC}$ also increasing CRF and vice-versa. The present study appoints that High PE participation is important to minimize the negative longitudinal effects of fatness on CRF.

Keywords: Physical Fitness; Exercise; Health; Schools; Physical Education and Training

\footnotetext{
${ }^{1}$ Santa Catarina State Department of Education - EEB Profa. Gracinda Augusta Machado (GAM), Rua 9 de Julho, Nova Brasília, Imbituba, Santa Catarina, Brazil. Postal Code 88780-000. Email: vanilson.lemes@ hotmail.com

${ }^{2}$ Lutheran University of Brazil, Campus São Jerônimo. Rua Antônio de Carvalho. São Jerônimo/ RS. Postal Code 96,700000. E-mail: rbmoreira2@gmail.com
}

Receipt date: 12/05/2021. Accepted for publication: 19/05/2021

Date of publication:15/10/2021.

Persp. Online: biol \& saúde, Campos dos Goytacazes, 39 (11) 37 - 57, 2021

ojs3.perspectivasonline.com.br 


\title{
RELAÇÕES MÚLTIPLAS LONGITUDINAIS DE PARTICIPAÇÃO NA EDUCAÇÃO FÍSICA, GRAU ESCOLAR, IDADE E SEXO COM MUDANÇAS DE APTIDÃO CARDIORPIRATÓRIA EM CRIANÇAS: UM PAPEL MEDIADOR DAS MUDANÇAS NA COMPOSIÇÃO CORPORAL
}

\author{
Vanilson Batista Lemes ${ }^{1 *}$ \& Rodrigo Baptista Moreira ${ }^{2}$
}

\begin{abstract}
RESUMO
LEMES, V.B; MOREIRA, R. B. Relações múltiplas longitudinais de participação na educação física, grau escolar, idade e sexo com mudanças de aptidão cardiorpiratória em crianças: um papel mediador das mudanças na composição corporal. Perspectivas Online: Biológicas \& Saúde, v.11, n.39, p. 37 - 57, 2021.

Verificar as relações múltiplas da participação na educação física, ano escolar, idade e sexo com as alterações longitudinais da aptidão cardiorrespiratória em crianças e identificar se existe um papel mediador das alterações longitudinais da composição corporal nessas relações. Métodos: Trata-se de um estudo longitudinal, realizado de março a novembro de 2019, com crianças de 6 a 12 anos, 150 meninos e 80 meninas. Classificou-se as crianças conforme um ponto de corte de $70 \%$ de participação nas aulas de educação física $(>70 \%=$ alta PEF $\mathrm{x}<70 \%=$ baixa PEF). Avaliaram-se os desfechos de Composição Corporal (CC): índice de massa corporal, dobras cutâneas, relação cintura / estatura e aptidão cardiorrespiratória (APCR). Utilizou-se estatística por delta individual $(\Delta \%), \mathrm{D}$ de

estimativas generalizadas (GEE) e modelo de equações estruturais (SEM). Resultados: meninos e meninas tiveram aumento nas variáveis de $\mathrm{BC}$ e uma diminuição longitudinal na CRF mais forte no grupo com baixa PEF em comparação com o grupo com alta PEF. O modelo SEM mostrou que as crianças com alta PEF tiveram grandes diminuições nas variáveis de BC e isso teve influência no aumento da APCR. Conclusão: $O$ grupo de alta PEF foi associado ao aumento do $\triangle \%$ APCR, essa é uma associação indireta mediada pela redução do $\Delta \% \mathrm{CC}$. O SEM indica que crianças que reduzem a $\mathrm{CC}$ também aumentaram a APCR e vice-versa. O presente estudo aponta que alta PEF é importante para minimizar os efeitos longitudinais negativos da gordura corporal sobre a APCR.
\end{abstract} Cohen, teste de Bonferroni, equações

Palavras-Chave: Aptidão Física; Exercício; Saúde; Escolas; Educação Física e Treinamento

\footnotetext{
${ }^{1}$ Secretaria de Estado da Educação de Santa Catarina - EEB Prof. Gracinda Augusta Machado (GAM), Rua 9 de julho, Nova Brasília, Imbituba, , Santa Catarina, Brasil CEP 88780-000. E-mail: vanilson.lemes@ hotmail.com

${ }^{2}$ Universidade Luterana do Brasil, Campus São Jerônimo. Rua Antônio de Carvalho. São Jerônimo/RS CEP 96.700-000. Email: rbmoreira2@gmail.com 


\section{INTRODUCTION}

A direction about the association between body composition (BC) and cardiorespiratory fitness (CRF) with physical activity practice still causes academic and practical discussions, especially in the interpretation of research results when it comes to cross-sectional data (GRALLA et al., 2019).

Regarding this, there is a suggestion that CRF as an intervenient factor for physical activity practice effects on BC (WISNIESKI; DALIMONTE-MERCKLING; ROBBINS, 2019). Another study showed that CRF is the link of less BC associated with better cardiometabolic health (ANDERSEN et al., 2015). Besides, another aut hors showed that BC can be an intervenient negative factor for the CRF relation with less cardiometabolic risk (BRAND et al., 2018; GRALLA et al., 2019; PÉREZ-BEY et al., 2019).

Additionally, classical theoretical perspectives suggest that CRF is correlated with high intensities of physical activity, better BC (FAIRCLOUGH, 2003), and cardiovascular health profiles in specific and independent form according to age and sexes (BERGMANN; BERGMANN; HALLAL, 2014; FAIRCLOUGH, 2003; GORAN et al., 2000; GRALLA et al., 2019; MCMURRAY et al., 1998; MILANESE et al., 2020).

These different results are generated due to methodologic aspects as statistical limitations, the general view about science, the measures errors, the lack of body fat-free mass measures, the BMI measure limitations, sample characteristics, and different kinds of CRF field evaluation tests (BERGMANN; BERGMANN; HALLAL, 2014; FAIRCLOUGH, 2003; GORAN et al., 2000; GRALLA et al., 2019; MCMURRAY et al., 1998; MILANESE et al., 2020). However, in practice and applicable view for physical education teaching and management of physical exercise for children health promotion (KAHAN; MCKENZIE, 2015; MCKENZIE; LOUNSBERY, 2013), the upper cited studies thesis suggested when there is an improvement, as a fatness decrease in $\mathrm{BC}$ also there is an increase in CRF and vice versa (BERGMANN; BERGMANN; HALLAL, 2014; FAIRCLOUGH, 2003; GORAN et al., 2000; GRALLA et al., 2019; MCMURRAY et al., 1998; MILANESE et al., 2020).

Some of these results come from mediation analyses conception (BRAND et al., 2018; PÉREZ-BEY et al., 2019; WISNIESKI; DALIMONTE-MERCKLING; ROBBINS, 2019). It is probably that mediation analyses are possible and applicable because of the CRF positive relation with lean body mass (BERGMANN; BERGMANN; HALLAL, 2014; FAIRCLOUGH, 2003; GORAN et al., 2000; GRALLA et al., 2019; MCMURRAY et al., 1998; MILANESE et $a l ., 2020$ ) and it is due to the maximal volume of oxygen (vo2máx) is relative and indissociable of the total body mass and BC measures when measured in field tests battery (BERGMANN et al., 2014; VALENTE-DOS-SANTOS et al., 2015; WERNECK et al., 2019). In other words, in reality, there is no separation between CRF (relative to values in field tests) of the BC due to these two factors were dependents on practice evaluation of CRF (BERGMANN; BERGMANN; HALLAL, 2014; FAIRCLOUGH, 2003; GORAN et al., 2000; GRALLA et al., 2019; MCMURRAY et al., 1998; MILANESE et al., 2020). It is perspective presents that BC can compose allometry of CRF and always is an intervenient factor for relative Vo2máx and CRF (BERGMANN et al., 2014; VALENTE-DOS-SANTOS et al., 2015; WERNECK et al., 2019).

In this sense, the present research intends and suggests another point of view about BC and CRF associations in a longitudinal latent mediation model (CHEUNG; LAU, 2008) with

Persp. Online: biol \& saúde, Campos dos Goytacazes, 39 (11) 37 - 57, 2021

ojs3.perspectivasonline.com.br 
another possible factors that has an impact on BC and CRF. About this, it is important to evaluate the changes and relations of BC and CRF in children and youth according to school physical education class participation (BLAIR; CHENG; HOLDER, 2001; COLQUITT et al., 2016; FAIRCLOUGH, 2003; KAHAN; MCKENZIE, 2015; LANGFORD et al., 2014; MILANESE et al., 2020), considering the school grade context, effects of sex, and age on BC and CRF (BARANOWSKI et al., 2013; BERGMANN et al., 2014; MILANESE et al., 2020; VALENTE-DOS-SANTOS et al., 2015; WERNECK et al., 2019).

Some research suggests that is possible to increase the CRF condition and also is probable to reduce the fatness in BC at physical education interventions (BRAND et al., 2019, 2020; GARCIÁ-HERMOSO et al., 2020; LEMES et al., 2019; OLIVEIRA et al., 2017). It occurs when well-planned and well-applicable classes with physical exercise, gymnastics, sports in school context (BRAND et al., 2019, 2020; GARCIÁ-HERMOSO et al., 2020; LEMES et al., 2019; OLIVEIRA et al., 2017). In this kind of intervention, the longitudinal changes in body composition had effects for fatness reduction, about $5 \%$ to $10 \%$, and CRF was improved by about $10 \%$ to $30 \%$ (BRAND et al., 2019, 2020; GARCIÁ-HERMOSO et al., 2020; LEMES et al., 2019; OLIVEIRA et al., 2017). From this, it is possible to hightlight the importance of physical education content as gymnastic, sports and the professor role in planning actions together with schools to improve the quality of life and children's learning about human movement culture (JUNIOR et al., 2012; SANTOS et al., 2013).

However, a systematic review showed that is scarce and inconclusive the knowledge about how the traditional physical education participation impacts the relation among $\mathrm{BC}$ with CRF considering a tracking of longitudinal data (GRALLA et al., 2019). Nevertheless, little is known about how Brazilian physical education classes without a specific health promotion intervention affects BC and CRF in children (BRAND et al., 2019, 2020; GARCIÁHERMOSO et al., 2020; LEMES et al., 2019; OLIVEIRA et al., 2017). There is a necessity of a study most complex considering weights of possible determinant factors as sex, age, and school grade in the same mediation analysis model to understand how BC and CRF have relations through the baseline to follow-up evaluations (BRAND et al., 2018, 2019, 2020; GARCIÁ-HERMOSO et al., 2020; LEMES et al., 2019; OLIVEIRA et al., 2017).

Monitoring of these aspects is important to improving, planning, having theoretical justifications, and to suggest for public managers providence more recurses, and structural conditions (DIAS et al., 2017; JUNIOR et al., 2012; SANTOS et al., 2013) for physical education at school in the Brazilian context. Thus, the present study aims to verify the multiple relations of physical education participation, school grade, age, and sex with longitudinal cardiorespiratory fitness changes in children and to identify if there is a mediator role of longitudinal body composition changes in these relations.

\section{METHODOLOGY}

\subsection{Study design and ethical procedures}

It is an observational longitudinal study with a follow-up case controlled by two groups according to children participating in classes of physical education. The present study was done according to the STROBE statement(STROBE STATEMENT, 2018). The baseline to followup evaluation occurs in 36 weeks. It was previously planned according to a project of physical fitness and following in a southern school of Santa Catarina, Brazil. This project was approved by the research ethics committee from Estacio de Sá - University Center - São José, according

Persp. Online: biol \& saúde, Campos dos Goytacazes, 39 (11) 37 - 57, 2021

ojs3.perspectivasonline.com.br 
to number: CAAE 25315518.4.0000.5357 - Approval: 3.758.311. All parents and legal guardians for children enrolled in this research sign consent and free research terms. The Helsinki declaration ethical procedures in research with humans were followed in all moments of this study (WORLD MEDICAL ASSOCIATION, 2013).

\subsection{Population and sample selection}

The flowchart in figure 1 showed the process of eligible sample selection. The invited population was 700 students who regularly enrolled at school in the south of Santa Catarina. From these students, only 322 children and youth were present in cardiorespiratory fitness and body composition evaluations in baseline occurred in the first week of March 2019. These participants were initially included because they agree with the voluntary form and to be present consent free and form terms assigned by parents and legal guardians.

At follow-up evaluation, in the last week of November 2019, only 230 children were present with the assignment terms and consent that results in CRF and BC tests were used for scientific research. The main eligibility criteria to include children in the present study were, to have no missing data in CRF or BC, and to be present at school in the follow-up period.

According to these aspects, the sample was composed of 230 children from 6 to 12 years old, 150 boys and 80 girls. All procedures for sample inclusion and exclusion can be seen in detail in the flowchart in figure 1, as well as, the school grade and the number of students in each grade.

Persp. Online: biol \& saúde, Campos dos Goytacazes, 39 (11) 37 - 57, 2021 


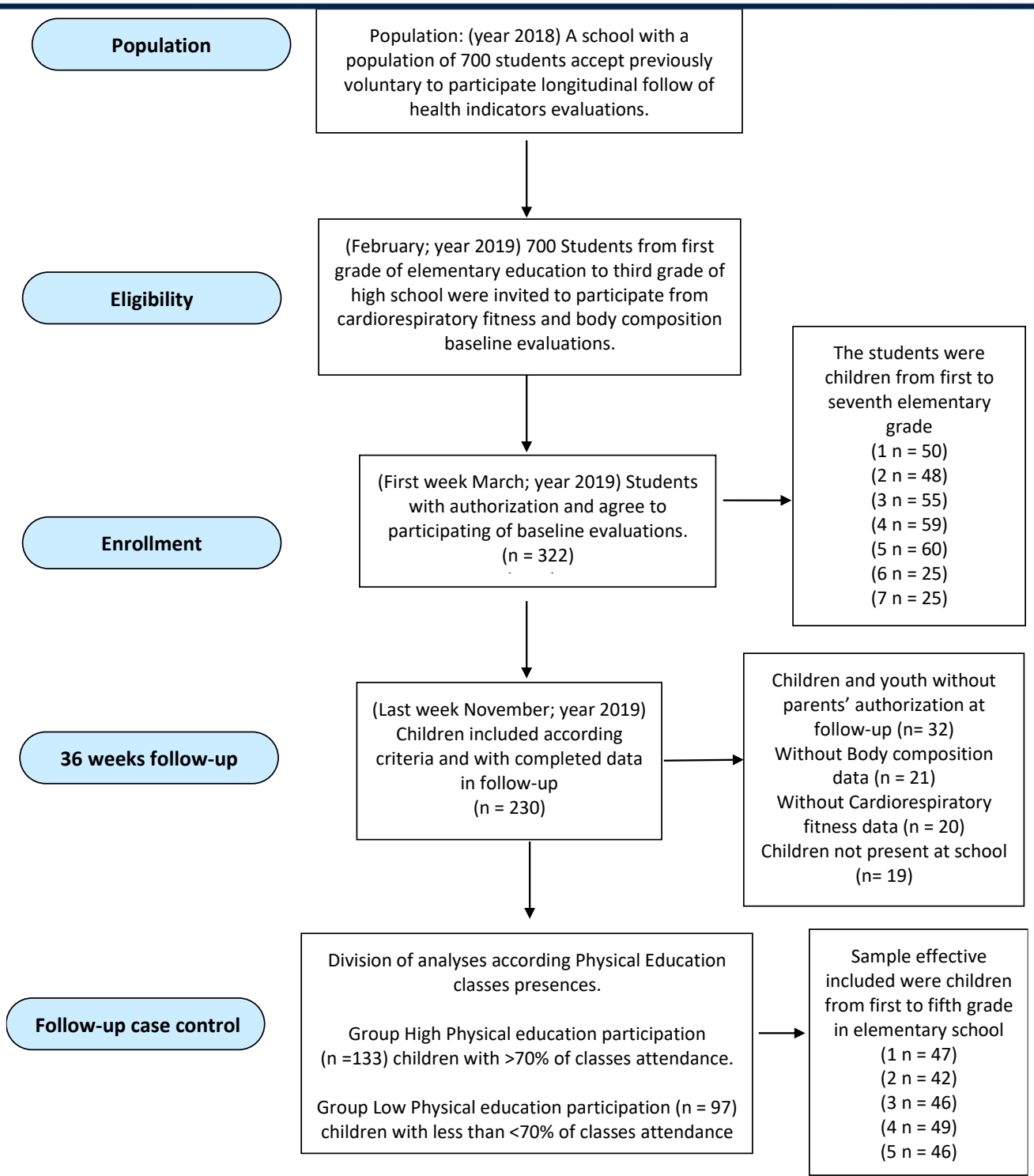

Figure 1. Flowchart according to STROBE recommendations (STROBE STATEMENT, 2018).

\subsubsection{Sample size power}

The sample size calculation was made a posteriori on the $\mathrm{G}^{*}$ Power 3.1 program (FAUL et al., 2007). Multivariate generalized linear models and structural mediation equations (CHEUNG; LAU, 2008) were considered with 10 observed variables a test power $(1-\beta)=0.85$, relation strength of 0.20 , and error of $5 \%$. Thus, the sample size of 230 was established as adequate (FAUL et al., 2007).

\subsection{Physical Education and classes participation controlling}

The Physical Education classes for the first to fifth grade of elementary school were established according to the curricula basis of Santa Catarina State (SANTA CATARINA, 2019). According to this document, the knowledge objects of physical education for children ranged between 6 to 12 years old were Sports, gymnastics, dance, games, recreation, and 
physical activities for the development of motor skills, affectivity, social abilities, integration, movement competence, and autonomy (BNCC, 2019; SANTA CATARINA, 2019).

The physical education program was conducted with only one teacher for 230 children present in this sample. This professional had 12 classes, approximately a total of 300 students, working in two school shifts, morning and afternoon, totally work with 36 classes with only 4 hours of planning by week. Each class had 45 minutes, and the frequency of physical education was three times a week by each school grade and class.

Specific in this school, the physical education classes at fifth elementary grade occur in a week on the open sports court into the school environment. This place was alternatively changed in posteriorly week with other teachers, responsible per classes of youths in sixth grade to ninth grade of elementary and with high school. When it was no possible to use school the sports court, the classes for children occur in adapted form indoor at the classroom, or in a Playground, with movement skills, sports, dance, and games as central classes priority.

The present school physical education teachers controlled all yearly 120 physical education classes attendance and presence from each student according to school call record data system, and smartphone android applicative: https://play.google.com/store/apps/details?id=br.gov.sc.ciasc.professorsc\&hl=pt_BR. Thus, children with high scholar frequency (High PE group) in physical education were those with $70 \%$ or more presences in physical education classes.

\subsection{Outcome evaluations}

Two professionals (a man and; a woman) of physical education with 10 years of experience in physical fitness and anthropometric evaluation were invited by the school for carried out the baseline evaluation and the same professionals conducted the follow-up evaluations.

\subsubsection{Body composition variables}

It was measured according to previous studies (GAYA et al., 2017; HEYWARD, 1998). Height and body mass were measured in all subjects who were clothing physical education uniforms, without shoes, and after having school breakfast in the morning or lunch in the afternoon shift. Body mass was measured to the nearest $0.10 \mathrm{~kg}$, using an electronic weight scale (OMROM digital weight measuring model HBF-214) and body height was measured with the participant standing up without shoes, on a metric tape fixed on the wall and extended from the bottom upwards, children were with posteriorly part of feet and trunk touching the wall, BMI was obtained according to a division of body mass per height in meters squared (BERGMANN et al., 2014; GAYA; GAYA, 2016; GAYA et al., 2018; OLIVEIRA et al., 2017). Waist circumference was measured to the nearest centimeter with a metallic tape at the superior border of the iliac crest (GAYA et al., 2017). Waist to Height Ratio (WhR) was measured by the division of waist circumference in centimeters by height in centimeters (ASHWELL, 2011).

The sum of triceps and mid-calf skinfolds were measured according to following the established protocols in millimeters (HEYWARD, 1998). It was used a Harpenden Skinfold Calipers, the evaluator men applied tests in boys and the woman in girls. Each skinfold was measured twice consecutively, on the right side of the body. If measurements differed by> 5\%,

Persp. Online: biol \& saúde, Campos dos Goytacazes, 39 (11) 37 - 57, 2021

ojs3.perspectivasonline.com.br 
a third measure was taken (GAYA et al., 2017). The average of measurements in each skinfold was calculated with bases in two best measures, and posteriorly the sum of tricipital and midcalf measures was done (GAYA et al., 2017; HEYWARD, 1998).

\subsubsection{Cardiorespiratory fitness}

The test of cardiorespiratory fitness was the walk/run 6 minutes test validated in Brazil in children and youth by PROESP-BR protocol (BERGMANN et al., 2014; GAYA; GAYA, 2016; GAYA et al., 2018; OLIVEIRA et al., 2017). The children should accomplish the greatest number of turns, running or walking, in a sports court with the volleyball perimeter marked with cones and the ground with indications of meters (LEMES et al., 2018). The measurement of the test was noted from the number of laps performed, plus the meters in the case of those who at the end of the time did not complete a full lap. After, the evaluators multiplying the number of laps by the perimeter of meters covered was obtained the estimate of CRF in meters performed in 6 minutes (LEMES et al., 2018).

\subsubsection{Control and independent variables}

The height, school grade, sex, and age were considered the main independent and control variables for outcome changes in BC and CRF in the present study. The physical education participation was considered an independent variable in dichotomic form considering the children achieve a minimum frequency of $70 \%$ or more classes attended in a scholar year as group (1) High Physical Education participation (High PE), and those achieved less than $70 \%$ ( $<84$ classes) were considered as a group (0) Low Physical Education participation (Low $\mathrm{PE})$.

\subsection{Statistical analyses}

First, there was an exploration of data basis to evaluate the missing cases. Normality and preliminary linear relations carried out with inspection according to box-plot graphs, normality multivariate curves, and Kolmogorov Smirnov test for all outcomes was applied. Thus, we established a description of the sample regarding the $\mathrm{BC}$ and CRF according to variance means, considering Cohens $\mathrm{D}$ effects of sexes and differences between three age classifications from 6 to 7, 8 to 9, and 10 to 12 years old. Cohens D was considered relevant sex effect (small to moderate) if higher than 0.30 (COHEN, 1992; PLICHTA; KELVIN, 2012) in each age classification. The Bonferroni significance post hoc analyses were adopted to detect differences at baseline measures, considering an alpha of $5 \%$ in the generalized estimative equation model (GEE).

After, considering previous studies the longitudinal changes of $\mathrm{BC}$ and $\mathrm{CRF}$ were estimated in percentual variation (BRAND et al., 2020; LEMES et al., 2018) for each child $(\Delta \%)$. This $\Delta \%$ was calculated according to the formula: outcome crude variable value at follow-up, minus the value at baseline, divided by baseline value multiplied per 100 (BRAND et al., 2020; LEMES et al., 2018). This procedure created new variables of individual changes from baseline to follow-up: $\Delta \% \mathrm{BMI}, \Delta \%$ of skinfolds (SKIN-F), $\Delta \% \mathrm{WhR}$, and $\Delta \% \mathrm{CRF}$. Hence, the longitudinal changes are described and compared according to bootstrapping with 1000 resamples and confidence intervals of $95 \%$ of probability in GEE (CHEUNG; LAU, 2008). Considering control for growth with $\Delta \%$ of Heigth, age, moderation for sexes, and school grade adjustment. The differences between High PE and Low PE groups were calculated

Persp. Online: biol \& saúde, Campos dos Goytacazes, 39 (11) 37 - 57, 2021 
according to GEE robust method and Bonferroni differences were described with pairwise adjustments (MCCORMACK et al., 2011).

\subsubsection{The longitudinal associations and mediation role}

To established the latent construct of $\mathrm{BC}$ and the theoretical relation of changes in $\mathrm{BC}$ were according to possible $\mathrm{CRF}$ increasing we calculated the reverse values $\Delta \%$ for $\mathrm{BMI}$, SKIN-F, and WhR through the multiplication of individual $\Delta \%$ values per (-1). It was done to preserve and facilities the theoretical logic in SEM. Thus, Figure 2 shows the multiple mediation model established according to the present theory to verify if latent body composition longitudinal changes construct is a mediator for the relation of physical education participation, age, sex, and school grade associations with longitudinal changes in cardiorespiratory fitness. We carried out the Mahalanobis test and it was verified the centroid $\boldsymbol{D}$ distance for all children and all variables included in the model (CHEUNG; LAU, 2008; HU; BENTLER, 1999; LEMES et al., 2020). For preserving the statistical power and for testing of mediation total, direct and indirect effects, we performed a bootstrapping mediation estimative in AMOS for non-normal distribution variables according to theoretical specifics approaches (CHEUNG; LAU, 2008; HU; BENTLER, 1999), in testing for 1000 re-samples, with confidence intervals of 95\% considering CFMIN/DF; TLI, CFI, IFI, RMSEA as goodness fit model (CHEUNG; LAU, 2008; HU; BENTLER, 1999; LEMES et al., 2020). The Goodman significance test for bootstrapping was adopted with alpha ranged at 5\% and confidence intervals with 95\% probability (CHEUNG; LAU, 2008; HU; BENTLER, 1999). The results of the proposed model (figure 1 and table 3 ) were presented in a table with confidence intervals, and standardized beta $(\beta)$ total, direct and indirect effects. All statistical analyses come from AMOS and IBM SPSS 22.0 .

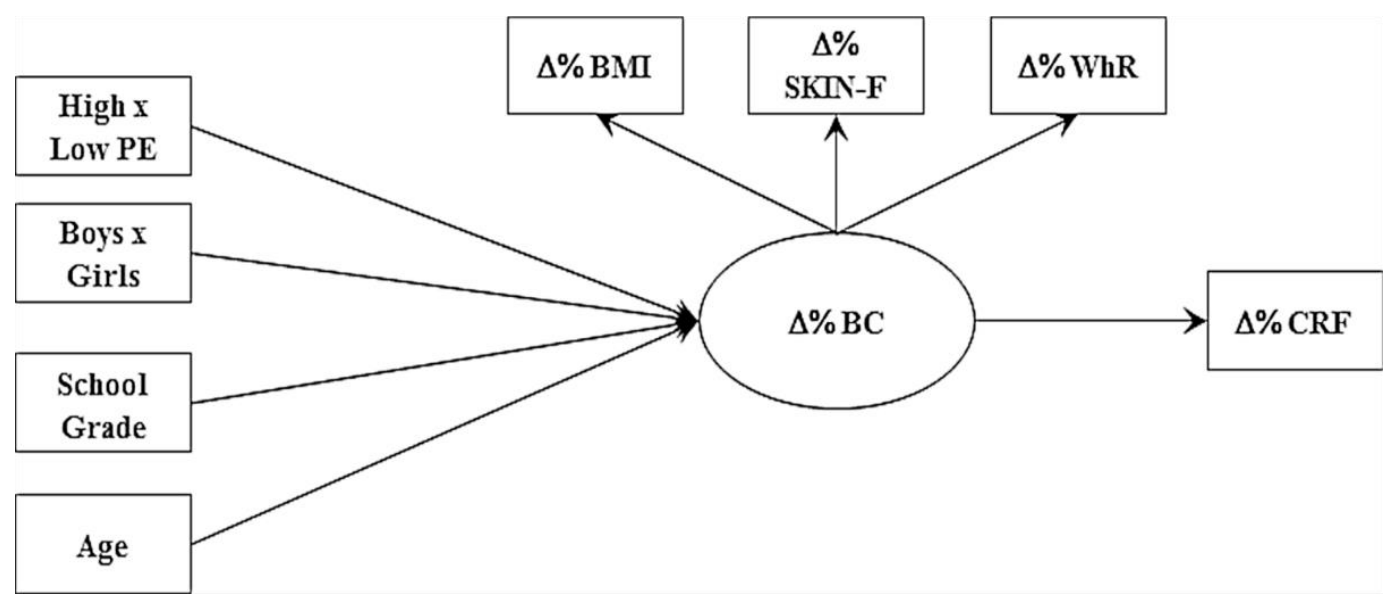

Figure 2. The mediator effect of BC longitudinal changes physical education participation, sex, school grade, and age relations with cardiorespiratory fitness longitudinal changes. $\Delta \% \mathrm{BMI}, \mathrm{SKIN}-\mathrm{F}, \mathrm{WhR}$ are reverse values of body mass index, skinfolds, and waist to height ratio longitudinal changes. High PE x Low PE is the variable according to physical education participation High was (1) and Low was (0). Boys x Girls, boys were (1) and girls were (0).

Persp. Online: biol \& saúde, Campos dos Goytacazes, 39 (11) 37 - 57, 2021

ojs3.perspectivasonline.com.br 


\section{RESULTS}

Table 1 shows the descriptive characteristics of variables sample with sex Cohens D effect and age comparisons. In this first analysis, we perceive that sex has a small to moderate effect on height and SKIN-F crude values at baseline ages of 6 to 7 years old. Girls had less height and higher values of SKIN-F than boys. In another way, the girls were more height than boys and presented fewer values of CRF and WhR than boys in 10 to 12 years old. Regarding age differences at baseline, it is possible observing that girls' body mass and height between 10 to 12 years old were higher than all other ages. In boys, the differences occur in all variables except WhR. In general, the 10 to 12 years old boys presented more body mass, height, CRF, BMI, and SKIN-F than 6 to 7 and 8 to 9 years old. 
Table 1. Descriptive characteristics of variables sample with sex D Cohens effect and age comparison.

\begin{tabular}{|c|c|c|c|c|c|c|c|c|c|c|c|c|c|c|c|c|}
\hline \multirow{3}{*}{ Variables crude } & \multirow{3}{*}{$\begin{array}{l}\text { Ages } \\
6 \text { to } 7\end{array}$} & \multicolumn{5}{|c|}{ Girls (baseline) } & \multicolumn{5}{|c|}{ Boys (baseline) } & \multirow{3}{*}{$\begin{array}{c}\begin{array}{c}\text { D Cohen } \\
\text { Sex }\end{array} \\
-0.15\end{array}$} & \multicolumn{4}{|c|}{ Age comparison* girls and boys } \\
\hline & & \multirow{2}{*}{$\frac{\mathbf{N}}{28}$} & \multirow{2}{*}{$\begin{array}{c}\text { Mean } \\
23.55\end{array}$} & \multirow{2}{*}{$\begin{array}{c}\text { SD } \\
5.80\end{array}$} & \multicolumn{2}{|c|}{ CI95\% (low-upper) } & \multirow{2}{*}{$\frac{\mathbf{N}}{37}$} & \multirow{2}{*}{$\begin{array}{c}\text { Mean } \\
24.39\end{array}$} & \multirow{2}{*}{$\begin{array}{c}\text { SD } \\
5.75\end{array}$} & \multicolumn{2}{|c|}{ CI95\% (low-upper) } & & \multirow[t]{2}{*}{ Girls (F) } & \multirow[t]{2}{*}{ p } & \multirow[t]{2}{*}{ Boys (F) } & \multirow[t]{2}{*}{ p } \\
\hline & & & & & 21.31 & 25.81 & & & & 22.48 & 26.31 & & & & & \\
\hline \multirow[t]{2}{*}{ Body mass (kg) } & 8 to 9 & 26 & 29.77 & 8.25 & 26.37 & 33.18 & 54 & 31.65 & 8.71 & 29.27 & 34.03 & -0.22 & 20.55 & 0.001 & 30.883 & 0.001 \\
\hline & 10 to 12 & 26 & 39.56 & 11.70 & 34.23 & 43.89 & 59 & 38.53 & 9.98 & 35.93 & 41.13 & 0.09 & & & & \\
\hline \multirow{3}{*}{ Height $(\mathbf{c m})$} & 6 to 7 & 28 & 119.33 & 5.54 & 117.18 & 121.48 & 37 & 121.48 & 7.34 & 119.03 & 123.93 & -0.33 & & & & \\
\hline & 8 to 9 & 26 & 131.63 & 7.77 & 128.42 & 134.84 & 54 & 132.89 & 7.33 & 130.89 & 134.89 & -0.17 & 70.49 & 0.001 & 83.441 & 0.001 \\
\hline & 10 to 12 & 26 & 144.38 & 9.43 & 140.49 & 148.27 & 59 & 141.38 & 7.39 & 139.45 & 143.30 & 0.35 & & & & \\
\hline \multirow{3}{*}{ CRF (meter/6min) } & 6 to 7 & 28 & 754.07 & 160.87 & 691.69 & 816.45 & 37 & 735.90 & 113.60 & 698.03 & 773.78 & 0.13 & & & & \\
\hline & 8 to 9 & 26 & 793.92 & 132.43 & 739.25 & 848.59 & 54 & 821.74 & 150.90 & 780.55 & 862.93 & -0.20 & 2.16 & 0.122 & 13.054 & 0.001 \\
\hline & 10 to 12 & 26 & 845.13 & 180.21 & 770.75 & 919.52 & 59 & 901.45 & 180.36 & 854.45 & 948.45 & -0.31 & & & & \\
\hline \multirow{3}{*}{ BMI $\left(\mathbf{k g} / \mathbf{m}^{2}\right)$} & 6 to 7 & 28 & 17.44 & 3.43 & 16.11 & 18.77 & 37 & 16.63 & 2.49 & 15.80 & 17.46 & 0.27 & & & & \\
\hline & 8 to 9 & 26 & 17.38 & 3.18 & 16.06 & 18.69 & 54 & 18.11 & 3.82 & 17.07 & 19.15 & -0.21 & 2.08 & 0.132 & 8.905 & 0.001 \\
\hline & 10 to 12 & 26 & 19.39 & 5.16 & 17.26 & 21.52 & 59 & 19.73 & 3.86 & 18.73 & 20.74 & -0.08 & & & & \\
\hline \multirow{3}{*}{ WhR (cm) } & 6 to 7 & 28 & 0.45 & 0.05 & 0.43 & 0.46 & 37 & 0.45 & 0.04 & 0.44 & 0.46 & -0.10 & & & & \\
\hline & 8 to 9 & 26 & 0.44 & 0.05 & 0.41 & 0.46 & 54 & 0.45 & 0.05 & 0.43 & 0.46 & -0.22 & 0.217 & 0.805 & 1.264 & 0.286 \\
\hline & 10 to 12 & 26 & 0.44 & 0.07 & 0.42 & 0.47 & 59 & 0.46 & 0.06 & 0.45 & 0.48 & -0.30 & & & & \\
\hline \multirow{3}{*}{ SKIN-F (mm) } & 6 to 7 & 28 & 24.05 & 10.04 & 20.16 & 27.94 & 37 & 20.17 & 6.92 & 17.86 & 22.48 & 0.45 & & & & \\
\hline & 8 to 9 & 26 & 25.82 & 11.44 & 21.10 & 30.55 & 54 & 25.66 & 12.72 & 22.19 & 29.13 & 0.01 & 2.117 & 0.128 & 5.946 & 0.003 \\
\hline & 10 to 12 & 26 & 30.56 & 13.78 & 24.87 & 36.25 & 59 & 28.69 & 13.21 & 25.25 & 32.13 & 0.14 & & & & \\
\hline
\end{tabular}

Mean values in bold indicate Bonferroni Post-Hoc test significative differences for an alpha less than 5\%. (N=230 of children participants in baseline and follow-up study).

CRF: cardiorespiratory fitness; BMI: body mass index; WhR: waist to height ratio; SKIN-F: the sum of tricipital and midcalf skinfolds.p=significance Bonferroni at alpha less than 5\%; (F): statistical F test value in generalized estimate equations; SD: standard deviation; CI95\% (low-upper): confidence intervals for a bootstrapping with 1000 retests and $95 \%$ of probability.

Persp. Online: biol \& saúde, Campos dos Goytacazes, 39 (11) 37 - 57, 2021

ojs3.perspectivasonline.com.br 
Table 2 presents the longitudinal percentage changes for each sex and with differences between physical education control groups (Low PE x High PE) considering an adjustment for age, growth according $\Delta \%$ to height, and school grade. The mean changes in $\mathrm{BC}$ and $\mathrm{CRF}$ variable according to individual percentage variation suggest that there is an increase in $\mathrm{BC}$ indicators and a decrease in CRF for boys and girls. However, it is possible to perceive that girls in the High PE group increasing Body Mass in lower (-3.47\%) and significative proportions compared to the Low PE group. The boys in the High PE group also have positive effects to maintain CRF (9.5\%) compared to those in the Low PE Group. Boys from the High PE have a $-2.4 \%$ increase in BMI compared to Low PE. It suggests that High PE participation protects boys and girls from poorer longitudinal changes in BC, and in CRF changes of boys, following 36 weeks, independently of growth, sex, age, or school grade effects.

Table 2. Percentual Longitudinal changes in cardiorespiratory fitness and anthropometric measures according to physical education participation in each sex

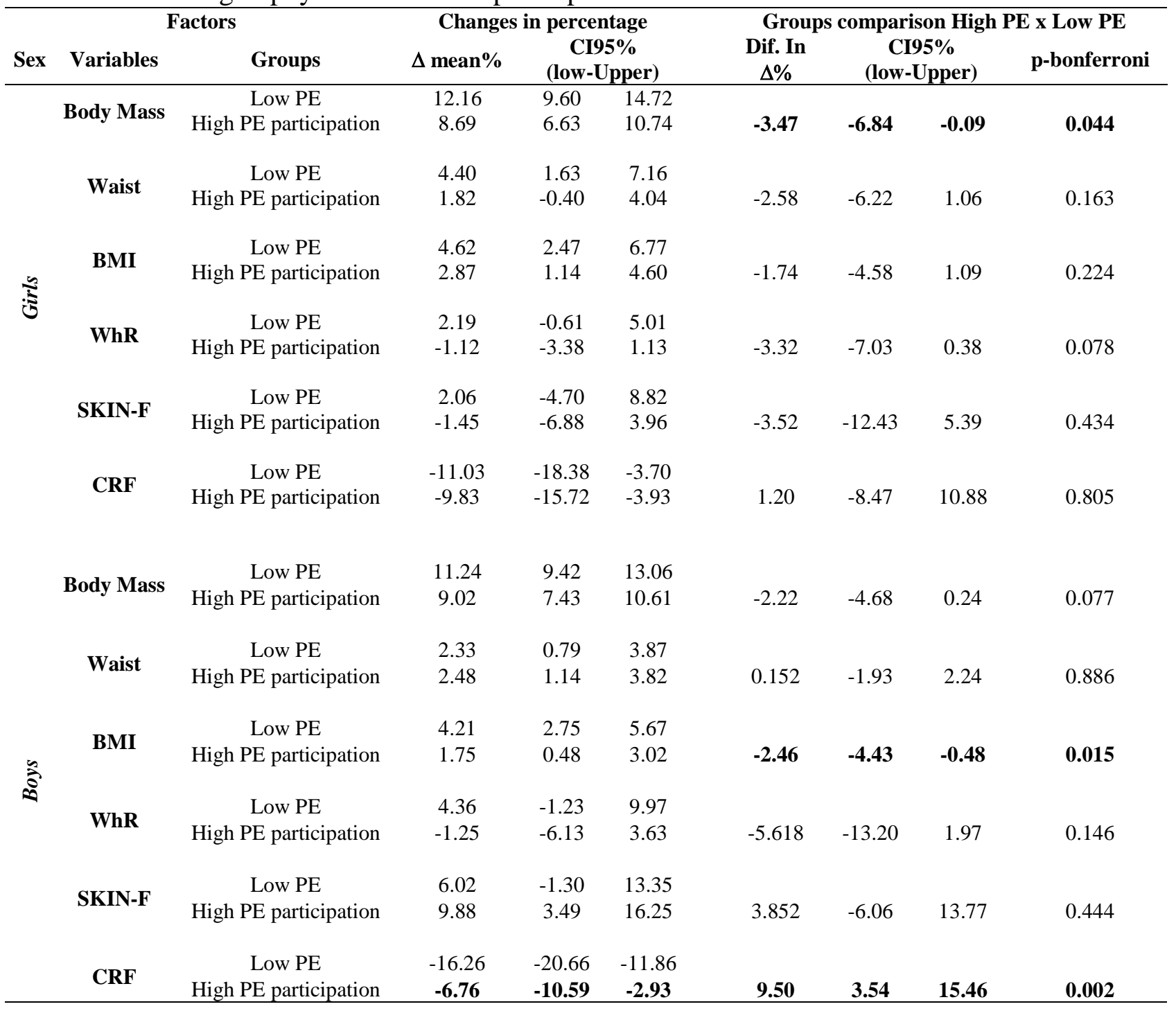

The analysis was adjusted: for 36 weeks of growth with $\Delta \%$ height, school grade, and ages. CRF: cardiorespiratory fitness; BMI: body mass index; WhR: waist to height ratio; SKIN-F: the sum of tricipital and midcalf skinfolds.p=significance Bonferroni at alpha less than 5\%; $(\mathrm{F})$ : statistical $\mathrm{F}$ test value in generalized estimate equations; SD: standard deviation; CI95\% (low-upper): confidence intervals for a bootstrapping with 1000 retests

Persp. Online: biol \& saúde, Campos dos Goytacazes, 39 (11) 37 - 57, 2021

ojs3.perspectivasonline.com.br 
and $95 \%$ of probability. $\Delta \%$ mean: individual variation means in percentual value for each outcome. High PE: High Physical Education participation Group; Low PE: Low physical education participation group.

Table 3 presents the figure 2 relation between physical education participation, age, school grade, and sex with CRF changes considering the mediation role of BC changes represented by the latent construct of reverse values in BMI, SKIN-F, and WhR. This model showed a goodness fit adequate according following values (CFMIN/DF: 1,67; TLI: 0,96; CFI:0,98; IFI:0,98; RMSEA:0,054). The correlations effects between control variables with High PE x Low PE group are: (age, $r=0.250 ; p=0.001$; school grade, $r=0.271 ; p=0.001$, sex, $0.040 ; p=0,876)$. These covariate results signifying that in the model presented in figure 2 , the children elder, and in a higher school grade also were those participating in a higher amount of physical education classes.

About the main mediation relation present in the model, it is possible to perceive that the High PE group has a significative total relation effect ( 0.08 to $0.33 \mathrm{z}$-scores) with latent $\Delta \% \mathrm{BC}$ reduction. The $\Delta \% \mathrm{BC}$ reduction has total positive effects related to an increasing of $\triangle \% \mathrm{CRF}$ with a mean of 0.21 , ranged (0.08 to 0.33 ). The main variable that explains the latent $\Delta \% \mathrm{BC}$ reduction, is $\Delta \% \mathrm{BMI}$ reduction, about 0.84 united z-scores ranged in a $\mathrm{CI}$ of 0.63 to 1.12. The direct effects are very similar to total effects. The High PE x Low PE group indirect effect (mediated) through $\Delta \% \mathrm{BC}$ reduction is significant, 0.04 in mean from 0.01 to 0.09 , and it occurs mainly according to $\Delta \% \mathrm{BMI}$ reduction. In practice these results indicating that children of High PE Group who have an increase in CRF. They also have a reduction necessarily on all variables of the latent variable of $\Delta \% \mathrm{BC}$ reduction to achieve the better CRF. 
Table 3. Results of SEM (figure 2): Total, direct and indirect effects for the latent body composition changes mediation role to physical education participation, school grade, age, and sex longitudinal association with cardiorespiratory fitness changes

\begin{tabular}{|c|c|c|c|c|c|c|c|c|c|c|c|c|c|c|c|c|c|c|c|c|}
\hline \multirow{3}{*}{$\begin{array}{c}\text { Total Z-score } \\
\text { Variables } \\
\end{array}$} & \multirow{2}{*}{\multicolumn{4}{|c|}{$\begin{array}{c}\text { Latent Mediator } \\
\Delta \% \mathrm{BC}(\text { decrease })\end{array}$}} & \multirow{2}{*}{\multicolumn{4}{|c|}{$\begin{array}{c}\text { Outcome } \\
\Delta \% \text { CRF (improvement) }\end{array}$}} & \multicolumn{12}{|c|}{ Latent mediator indicators } \\
\hline & & & & & & & & & \multicolumn{4}{|c|}{$\Delta \%$ SKIN-F (decrease) } & \multicolumn{4}{|c|}{$\Delta \% \mathrm{BMI}($ decrease$)$} & \multicolumn{4}{|c|}{$\Delta \% \mathrm{WhR}$ (decrease) } \\
\hline & $\beta$ & lower & upper & $\mathbf{p}$ & $\beta$ & lower & upper & $\mathbf{p}$ & $\beta$ & lower & upper & $\mathbf{p}$ & $\beta$ & lower & upper & $\mathbf{p}$ & $\beta$ & lower & upper & $\mathbf{p}$ \\
\hline Age & -0.03 & -0.36 & 0.30 & 0.919 & -0.01 & -0.08 & 0.06 & 0.919 & -0.01 & -0.19 & 0.13 & 0.919 & -0.02 & -0.30 & 0.26 & 0.919 & -0.01 & -0.14 & 0.16 & 0.919 \\
\hline School Grade & -0.01 & -0.32 & 0.30 & 0.931 & 0.00 & -0.07 & 0.07 & 0.931 & -0.01 & -0.15 & 0.15 & 0.931 & -0.01 & -0.28 & 0.26 & 0.931 & 0.00 & -0.17 & 0.12 & 0.931 \\
\hline Sex & 0.03 & -0.14 & 0.15 & 0.747 & 0.01 & -0.03 & 0.03 & 0.747 & 0.01 & -0.08 & 0.06 & 0.747 & 0.02 & -0.10 & 0.16 & 0.747 & 0.01 & -0.05 & 0.09 & 0.747 \\
\hline High PE x Low PE & 0.21 & 0.08 & 0.33 & 0.018 & 0.05 & 0.01 & 0.09 & 0.018 & 0.10 & 0.03 & 0.17 & 0.018 & 0.18 & 0.07 & 0.29 & 0.018 & 0.07 & 0.02 & 0.19 & 0.018 \\
\hline Latent $\Delta \% \mathrm{BC}$ reduction & & & & & 0.21 & 0.07 & 0.35 & 0.001 & 0.46 & 0.32 & 0.63 & 0.001 & 0.84 & 0.63 & 1.12 & 0.001 & 0.31 & 0.18 & 0.77 & 0.001 \\
\hline
\end{tabular}

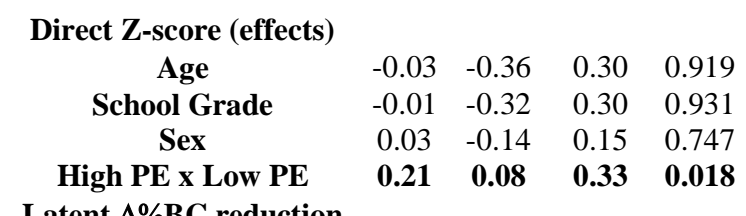

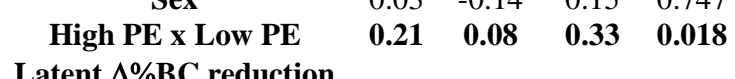

Latent $\Delta \% \mathrm{BC}$ reduction

\begin{abstract}
$\begin{array}{llllllllllllllll}0.20 & 0.07 & 0.35 & 0.018 & 0.46 & 0.32 & 0.63 & 0.010 & 0.84 & 0.63 & 1.12 & 0.018 & 0.31 & 0.18 & 0.77 & 0.018\end{array}$
\end{abstract}
Indirect Z-score (effects)

Age

Sex

High PE x Low PE
School Grade

$\begin{array}{cccccccccccccccc}-0.01 & -0.08 & 0.06 & 0.919 & -0.01 & -0.19 & 0.13 & 0.919 & -0.02 & -0.30 & 0.26 & 0.919 & -0.01 & -0.14 & 0.158 & 0.919 \\ 0.00 & -0.07 & 0.07 & 0.932 & -0.01 & -0.15 & 0.15 & 0.932 & -0.01 & -0.28 & 0.26 & 0.932 & 0.00 & -0.17 & 0.123 & 0.932 \\ 0.01 & -0.03 & 0.03 & 0.747 & 0.01 & -0.08 & 0.06 & 0.747 & 0.02 & -0.10 & 0.16 & 0.747 & 0.01 & -0.05 & 0.085 & 0.747 \\ \mathbf{0 . 0 4} & \mathbf{0 . 0 1} & \mathbf{0 . 0 9} & \mathbf{0 . 0 1 8} & \mathbf{0 . 1 0} & \mathbf{0 . 0 3} & \mathbf{0 . 1 7} & \mathbf{0 . 0 1 8} & \mathbf{0 . 1 8} & \mathbf{0 . 0 7} & \mathbf{0 . 2 9} & \mathbf{0 . 0 1 8} & \mathbf{0 . 0 7} & \mathbf{0 . 0 2} & \mathbf{0 . 1 9 1} & \mathbf{0 . 0 1 8}\end{array}$

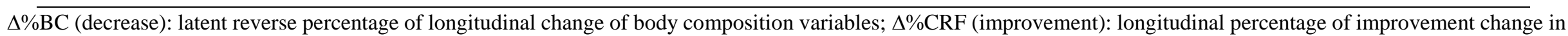
cardiorespiratory fitness; $\Delta \% \mathrm{SKIN-F}$ (decrease): reverse longitudinal percentage of change in skinfolds sum; $\Delta \% \mathrm{BMI}$ (decrease): reverse longitudinal percentage of change in body mass index; $\Delta \% \mathrm{WhR}$ (decrease): reverse longitudinal percentage of change in the waist to height ratio; $\beta$ : beta values in united of z-scores; (lower/upper): confidence intervals from a bootstrapping of 1000 retests according to Goodman; p: statistical significance less than alpha of $5 \%$. Values in bold were statistically significant. 


\section{DISCUSSION}

The present study results showed that girls had less height and higher values of SKIN$F$ than boys at an early age. Elder girls were most tall than boys, and younger girls. They present less CRF and WhR than boys, with more body mass than all other girls ages. Elder boys presented more body mass, height, CRF, BMI, and SKIN-F than more younger boys. Lifestyle changes across the ages and hormonal body modifications from boys as testosterone increasing at 10-12 years old and girls with more complex hormonal maturation can lead to a large gain in body measures, improvement of CRF for elder boys, and increased body fatness in elder girls(BERGMANN et al., 2014, 2007; BERGMANN; BERGMANN; HALLAL, 2014; ORTEGA et al., 2015).

Regarding longitudinal changes in BC and CRF from baseline to follow-up, the main results showed a critical risk situation for children's health according to the growth. It is possible to suggest that children with Low PE participation have unhealthy longitudinal changes in BC and CRF, compared to those with High PE participation. Boys in the High PE group present less CRF decreasing than the Low PE group (-6\% x -16\%). There were significant longitudinal differences between groups. It is showing high consistency to better results in the High PE group for girl's body mass, and boy's BMI and CRF compared to respective counterparts in Low PE group.

The general unhealthy longitudinal changes can be explained because children don't were in an intervention specific for obtaining better parameters in BC and CRF. The physical education with intervention objective in these variables is most effective according to multicomponent and multidisciplinary approaches and needs changes in general lifestyle (BRAND et al., 2019, 2020; GARCIÁ-HERMOSO et al., 2020; LEMES et al., 2019; OLIVEIRA et al., 2017). A fact that was difficult to be applicable in the present context if we consider the present physical education limitations. A single teacher to work, 36 scholar periods (classes) a week, 10 classes with 20 to 30 children, and 300 children to only one teacher control during all weeks in a year, without anyone, supports of health professionals like nutritionists or psychologies as in another intervention studies (BRAND et al., 2019, 2020; GARCIÁ-HERMOSO et al., 2020). Besides, present results are a consequence of a complex factor sum (KAHAN; MCKENZIE, 2015; MCKENZIE; LOUNSBERY, 2013; SALLIS et al., 2016), for example, the Brazilian law guidelines in physical education curricula are focused on other objectives for physical education that not were health promotion, motor skills development, sports, and physical exercise per self (BNCC, 2019; SANTA CATARINA, 2019). The aims as the development of social relation skills, sociability, and affective capacities were more highlighted in these proposes (BNCC, 2019; KNOPP; PRAT; AZEVEDO, 2014; SANTA CATARINA, 2019).

A sum of facts that difficult teaching for physical fitness, sports learning, and health promotion (KNOPP; PRAT; AZEVEDO, 2014). Additionally, the Brazilian schools' public context presents vulnerable situations (BENTO et al., 2019; GODOY et al., 2017; JUNIOR et al., 2012; SANTOS et al., 2013). Families and children sometimes don't know about healthy nutrition, they don't have basic food intake at home (BENTO et al., 2019; GODOY et al., 2017; NOBRE; VALENTINI; NOBRE, 2018) and in physical education, there is not an able time to teaching about this. It is a preoccupancy fact, linked hypothetically to other lifestyle behaviors and social problems likely children with a low level of physical activity, and general low fitness levels (GONÇALVES et al., 2018; LAROUCHE et al., 2012, 2014). It is hard for only a teacher

Persp. Online: biol \& saúde, Campos dos Goytacazes, 39 (11) 37 - 57, 2021

ojs3.perspectivasonline.com.br 
of physical education to intervene to help the increase in fatness indicators as $\mathrm{BC}$, and it can contribute to the reduction of CRF (GONÇALVES et al., 2018; MARTÍNEZ STEELE et al., 2018).

Finally, the present SEM showed a mediation role of changes in $\mathrm{BC}$ (decreasing), configured by reverse BC variables Z-scores. These results showed the association of the High PE participation group with the positive change in CRF is dependent (mediated) on a reduction of $\mathrm{BC}$ latent variable and, in practice, it is possible to have a vice versa relation (Low $\mathrm{PE}$ group $\rightarrow+\mathrm{BC} \rightarrow-\mathrm{CRF}$; $-\mathrm{CRF} \rightarrow+\mathrm{BC} \rightarrow$ Low PE). In our study, the correlations between independent mediation factors showed that children with more age and in higher school grades are in the High PE participation group and it providing less BC and more CRF, a fact associated probably with the autonomy, enjoyment in school activities, and high physical activity levels from high PE group (BERLEZE; VALENTINI, 2013; LEMES et al., 2015, 2020; OLIVEIRA et al., 2017).

The present mediation results are consistent according to two ways. The first shows that a decreasing in $\mathrm{BC}$ is hardly even in studies with approaching nutritional lifestyle changes (ALKHUDAIRY et al., 2017; BRAND et al., 2020; COLQUITT et al., 2016; MAGNUSSON et al., 2012), suggesting that large BC parameters as high BMI, SKIN-F, and WhR can be a boundary to longitudinal improvement in fitness variables as CRF (AL-KHUDAIRY et al., 2017; COLQUITT et al., 2016). This evidence was suggested in a systematic review (GRALLA et al., 2019). The second way was according to studies that suggest previous mediation roles and associations of $\mathrm{BC}$ and $\mathrm{CRF}$ as interdependent factors in the case of relative CRF measure (BERGMANN; BERGMANN; HALLAL, 2014; GORAN et al., 2000; MCMURRAY et al., 1998; MILANESE et al., 2020). In this sense studies also presented that free body fatness difficult the CRF increasing (GORAN et al., 2000; MAGNUSSON et al., 2012) and the relation of CRF with better health and physical activity associated with lower BC parameters (BRAND et al., 2018; GRALLA et al., 2019; HUSSEY et al., 2007). Thus, we can suggest that a possible improvement in $\mathrm{BC}$ is a mediator role to High PE participation associated with positive changes in CRF. A fact that not was showed in previous researches (BERGMANN et al., 2014; VALENTE-DOS-SANTOS et al., 2015; WERNECK et al., 2019).

The main contribution of the present study is a longitudinal approach to monitoring BC and CRF in children 6-12 years. The strengths are a structural equation model with supportable parameters, a case-control approach, a considerable sample size longitudinal data, and adequate consistency (CHEUNG; LAU, 2008; HU; BENTLER, 1999). Also, this study suggests in a practice way that it is necessary that one of the most important objectives of physical education being physical fitness improvements and health promotion (BRAND et al., 2019, 2020; GARCIÁ-HERMOSO et al., 2020; LEMES et al., 2019; OLIVEIRA et al., 2017). However, several limitations can be pointed: a necessity of a random representative sample, the lack of other possible intervenient factors as nutrition, longitudinal food intake, diet quality, maturation, physical activity levels out of school, and the control of intensity in physical education classes. Therefore, our research achieves the presented objective and it is one of the first to evaluate a considerable sample (230) of Brazilian children considering longitudinal changes in BC and CRF (BERGMANN et al., 2008; GONÇALVES et al., 2018).

\section{CONCLUSIONS}

Persp. Online: biol \& saúde, Campos dos Goytacazes, 39 (11) 37 - 57, 2021

ojs3.perspectivasonline.com.br 
In conclusion, this study showed an increase in BC and a decrease of CRF for boys and girls about $2 \%$ to $16 \%$ through longitudinal surveillance study in 36 weeks. Children with High PE participation are more protected for BC changes (effect about 6\%) and CRF (effect about 9\%) compared to children with Low PE participation even in a school without a planned physical education for health promotion. Through the present SEM, we suggest that children with High PE participation achieving $\mathrm{BC}$ reduction and it helps to a CRF increasing or maintaining in more proportion than Low PE group.

\section{REFERENCES}

AL-KHUDAIRY, L. et al. Diet, physical activity and behavioural interventions for the treatment of overweight or obese adolescents aged 12 to 17 years. Cochrane Database of Systematic Reviews, v. 2017, n. 6, p. CD012691, 22 jun. 2017.

ANDERSEN, L. B. et al. A new approach to define and diagnose cardiometabolic disorder in children. Journal of diabetes research, v. 2015, n. Cvd, p. 539835, 2015.

ASHWELL, M. The Increasing Importance of Waist-to-Height Ratio to Assess Cardiometabolic Risk: A Plea for Consistent Terminology. The Open Obesity Journal, v. 3, n. 0 , p. 70-77, 2011.

BARANOWSKI, T. et al. Prospective BMI Category Change Associated with Cardiovascular Fitness Change. Medicine and Science In Sports and Exercise, v. 45, n. 2, p. 294-298, 2013.

BENTO, G. G. et al. Prevalence and factors associated with physical activity in socially vulnerable children. Revista Brasileira de Medicina do Esporte, v. 25, n. 4, p. 285-289, 2019.

BERGMANN, G. et al. Use of the 6-minute walk/run test to predict peak oxygen uptake in adolescents. Revista Brasileira de Atividade Física \& Saúde, v. 19, n. 1, p. 64-73, 2014.

BERGMANN, G. G. et al. Peak growth velocity of height , body mass and subcutaneous fat in 10 to 14 -year-old boys and girls. Revista Brasileira de Cineantropometria \& Desempenho Humano, v. 9, n. 4, p. 333-338, 2007.

BERGMANN, G. G. et al. Estudo longitudinal do crescimento corporal de escolares de 10 a 14 anos: Diformismo sexual e pico de velocidade. Revista Brasileira de Cineantropometria \& Desempenho Humano, v. 10, p. 249-254, 2008.

BERGMANN, G. G.; BERGMANN, M. L. DE A.; HALLAL, P. C. Independent and combined associations of cardiorespiratory fitness and fatness with cardiovascular risk factors in Brazilian youth. Journal of physical activity \& health, v. 11, n. 2, p. 375-383, fev. 2014.

BERLEZE, A.; VALENTINI, N. C. Motor Development of obese and healthy weight children: A Mastery Climate Motor Skills Intervention impact on the motor development and body mass index. Journal Of Sport \& Exercise Psychology, v. 35, n. S, p. S60-S61, jun. 2013.

BLAIR, S. N.; CHENG, Y.; HOLDER, J. S. Is physical activity or physical fitness more important in defining health benefits? Medicine and science in sports and exercise, v. 33, $\mathrm{n}$.

Persp. Online: biol \& saúde, Campos dos Goytacazes, 39 (11) 37 - 57, 2021

ojs3.perspectivasonline.com.br 
6 Suppl, p. S379-S399; discussion S419-S420, 2001.

BNCC. Base Nacional Comum CurricularMinistério da Educação do Brasil, 2019. Disponível em: <http://basenacionalcomum.mec.gov.br/>. Acesso em: 14 jan. 2020

BRAND, C. et al. The role of body fat in the relationship of cardiorespiratory fitness with cardiovascular risk factors in Brazilian children. Motriz. Revista de Educacao Fisica, v. 24, n. 4, p. 101811, 2018.

BRAND, C. et al. Effect of a multicomponent intervention in components of metabolic syndrome: a study with overweight/obese low-income school-aged children. Sport Sciences for Health, n. 0123456789, 11 out. 2019.

BRAND, C. et al. Effects and prevalence of responders after a multicomponent intervention on cardiometabolic risk factors in children and adolescents with overweight/obesity: Action for health study. Journal of sports sciences, v. 38, n. 6, p. 682-691, 12 mar. 2020.

CHEUNG, G. W.; LAU, R. S. Testing mediation and suppression effects of latent variables: Bootstrapping with structural equation models. Organizational Research Methods, v. 11, n. 2, p. 296-325, 2008.

COHEN, J. Quantitative methods in psychology: a power primer. Psychological Bulletin, v. 112, n. (1), p. 153-159., 1992.

COLQUITT, J. L. et al. Diet, physical activity, and behavioural interventions for the treatment of overweight or obesity in preschool children up to the age of 6 years. Cochrane Database of Systematic Reviews, v. 2016, n. 3, p. CD012105, mar. 2016.

DIAS, A. F. et al. Association between school structure and physical activity in physical education class and school recess. Revista Brasileira de Cineantropometria e Desempenho Humano, 2017.

FAIRCLOUGH, S. J. Girls' physical activity during high school physical education: Influences of body composition and cardiorespiratory fitness. Journal of Teaching in Physical Education, v. 22, n. 4, p. 382-395, 2003.

FAUL, F. et al. G*Power 3: A flexible statistical power analysis program for the social, behavioral, and biomedical sciences. Behavior Research Methods, v. 39, n. 2, p. 175-191, 2007.

GARCIÁ-HERMOSO, A. et al. Association of Physical Education with Improvement of Health-Related Physical Fitness Outcomes and Fundamental Motor Skills among Youths: A Systematic Review and Meta-analysis. JAMA Pediatrics, p. 1-11, 2020.

GAYA, A. A.; GAYA, A. A. Projeto Esporte Brasil. Manual de testes e avaliação.Porto Alegre. Editora Perfil. Universidade Federal do Rio Grande do Sul, , 2016. Disponível em: <https://www.ufrgs.br/proesp/como-aplicar-o-proesp.php>

GAYA, A. R. et al. Obesity anthropometric indicators associated with cardiometabolic risk in

Persp. Online: biol \& saúde, Campos dos Goytacazes, 39 (11) 37 - 57, 2021

ojs3.perspectivasonline.com.br 
Portuguese children and adolescents. Preventive Medicine Reports, v. 8, n. September, p. 158-162, 6 dez. 2017.

GAYA, A. R. et al. Aggregation of risk indicators to cardiometabolic and musculoskeletal health in Brazilian adolescents in the periods 2008/09 and 2013/14. Jornal de Pediatria, v. 94, n. 2, p. 177-183, mar. 2018.

GODOY, K. et al. Insegurança alimentar e estado nutricional entre indivíduos em situação de vulnerabilidade social no Brasil. Ciencia e Saude Coletiva, v. 22, n. 2, p. 607-616, 2017.

GONÇALVES, E. C. DE A. et al. Prevalence of Brazilian children and youth who meet health criteria for cardiorespiratory fitness: Systematic review. Revista Brasileira de Cineantropometria e Desempenho Humano, v. 20, n. 4, p. 446-471, 2018.

GORAN, M. et al. Total body fat does not influence maximal aerobic capacity. International journal of obesity and related metabolic disorders: journal of the International Association for the Study of Obesity, v. 24, n. 7, p. 841-848, jul. 2000.

GRALLA, M. H. et al. Associations of Objectively Measured Vigorous Physical Activity With Body Composition, Cardiorespiratory Fitness, and Cardiometabolic Health in Youth: A Review. American Journal of Lifestyle Medicine, v. 13, n. 1, p. 61-97, 6 jan. 2019.

HEYWARD, V. H. Practical Body Composition Assessment for Children, Adults, and Older Adults. International Journal of Sport Nutrition, v. 8, n. 3, p. 285-307, 1 set. 1998.

HU, L.; BENTLER, P. M. Cutoff criteria for fit indexes in covariance structure analysis: Conventional criteria versus new alternatives. Structural Equation Modeling: A Multidisciplinary Journal, v. 6, n. 1, p. 1-55, jan. 1999.

HUSSEY, J. et al. Relationship between the intensity of physical activity, inactivity, cardiorespiratory fitness and body composition in 7-10-year-old Dublin children. British journal of sports medicine, v. 41, n. 5, p. 311-316, maio 2007.

JUNIOR, C. F. et al. A ginástica como conteúdo da educação física escolar. Perspectivas online: Biológicas \& Saúde, v. 5, n. 2, p. 12-22, 2012.

KAHAN, D.; MCKENZIE, T. L. The potential and reality of physical education in controlling overweight and obesity. American Journal of Public Health, v. 105, n. 4, p. 653-659, 2015.

KNOPP, D.; PRAT, I. A.; AZEVEDO, M. R. Intervenções escolares de médio e longo prazo para promoção de atividade física: Revisão sistemática. Revista Brasileira Atividade Física e Saúde, v. 19, n. 2, p. 142-152, 2014.

LANGFORD, R. et al. The WHO Health Promoting School framework for improving the health and well-being of students and their academic achievement. The Cochrane database of systematic reviews, v. 4, p. CD008958, 2014.

LAROUCHE, R. et al. Life transitions in the waning of physical activity from childhood to adult life in the Trois-Rivières study. Journal of physical activity \& health, v. 9, n. 4, p. 516-

Persp. Online: biol \& saúde, Campos dos Goytacazes, 39 (11) 37 - 57, 2021

ojs3.perspectivasonline.com.br 
24, maio 2012.

LAROUCHE, R. et al. Physical fitness, motor skill, and physical activity relationships in grade 4 to 6 children. Applied Physiology Nutrition and Metabolis. Physiologie Appliquee Nutrition et Metabolisme, v. 39, n. 5, SI, p. 553-559, 2014.

LEMES, V. B. et al. Níveis de atividade física em dois modelos de aulas de Educação Física. Cinergis, v. 16, n. 4, p. 231-236, 2015.

LEMES, V. B. et al. Jump gymnastic at school physical education for adolescents and adults: changes and prevalence of success in health-related physical fitness. Revista Brasileira de Atividade Física \& Saúde, v. 23, p. 1-10, 2018.

LEMES, V. B. et al. Efeitos da Educação Física nos níveis de aptidão cardiorrespiratória e no índice de massa corporal na Educação de Jovens e Adultos - EJA. Revista Brasileira de Educação Física e Esporte, v. 33, n. 4, p. 639-647, 2019.

LEMES, V. B. et al. Associations among psychological satisfaction in physical education, sports practice, and health indicators with physical activity: Direct and indirect ways in a structural equation model proposal. International Journal of Pediatrics and Adolescent Medicine, nov. 2020.

MAGNUSSON, K. T. et al. Limited effects of a 2-year school-based physical activity intervention on body composition and cardiorespiratory fitness in 7-year-old children. Health education research, v. 27, n. 3, p. 484-494, jun. 2012.

MARTÍNEZ STEELE, E. et al. Ultra-processed foods, protein leverage and energy intake in the USA. Public health nutrition, v. 21, n. 1, p. 114-124, jan. 2018.

MCCORMACK, G. R. et al. A cross-sectional study of the individual, social, and built environmental correlates of pedometer-based physical activity among elementary school children. The international journal of behavioral nutrition and physical activity, v. 8, p. 30, 2011.

MCKENZIE, T. L.; LOUNSBERY, M. A. F. Physical Education Teacher Effectiveness in a Public Health Context. Research Quarterly for Exercise and Sport, v. 84, n. August 2015, p. 419-430, 2013.

MCMURRAY, R. G. et al. Is physical activity or aerobic power more influential on reducing cardiovascular disease risk factors? Medicine and Science in Sports and Exercise, v. 30, n. 10, p. 1521-1529, out. 1998.

MILANESE, C. et al. The role of age, sex, anthropometry, and body composition as determinants of physical fitness in nonobese children aged 6-12. PeerJ, v. 2020, n. 3, 2020.

NOBRE, G. C.; VALENTINI, N. C.; NOBRE, F. S. S. Fundamental motor skills, nutritional status, perceived competence, and school performance of Brazilian children in social vulnerability: Gender comparison. Child Abuse and Neglect, v. 80, n. February, p. 335-345, 2018.

Persp. Online: biol \& saúde, Campos dos Goytacazes, 39 (11) 37 - 57, 2021

ojs3.perspectivasonline.com.br 
OLIVEIRA, L. C. V. DE et al. Effect of an intervention in Physical Education classes on health related levels of physical fitness in youth. Revista Brasileira de Atividade Física \& Saúde, v. 22, n. 1, p. 46-53, 2017.

ORTEGA, F. B. et al. Role of Fitness in the Metabolically Healthy but Obese Phenotype: A Review and Update. Progress in Cardiovascular Diseases, v. 58, n. 1, 2015.

PÉREZ-BEY, A. et al. The influence of cardiorespiratory fitness on clustered cardiovascular disease risk factors and the mediator role of body mass index in youth: The UP\&DOWN Study. Pediatric Diabetes, v. 20, n. 1, p. 32-40, 2019.

PLICHTA, S. B.; KELVIN, E. A. Munro's statistical methods for health care research, 2012.

SALLIS, J. F. et al. Series Physical Activity 2016: Progress and Challenges Progress in physical activity over the Olympic quadrennium. The Lancet, v. 6736, n. 16, p. 1-12, 2016.

SANTA CATARINA, G. DO E. DE. Currículo base da educação infantil e do ensino fundamental do território catarinense. Florianópolis. Secretaria de Estado da Educação, , 2019.

SANTOS, J. D. C. et al. O professor de educação física e sua participação na construção do Projeto Político Pedagógico da Escola. Perspectivas on-line: Biológicas \& Saúde, v. 8, n. 3, p. 9-22, 2013.

STROBE STATEMENT. Checklist of items that should be included in reports of crosssectional studies. STROBE-statement.org, p. 1-3, 2018.

VALENTE-DOS-SANTOS, J. et al. Allometric modelling of peak oxygen uptake in male soccer players of 8-18 years of age. Annals of human biology, v. 42, n. 2, p. 125-133, mar. 2015.

WERNECK, A. O. et al. Allometric scaling of aerobic fitness outputs in school-aged pubertal girls. BMC Pediatrics, v. 19, n. 1, p. 96, 8 abr. 2019.

WISNIESKI, L.; DALIMONTE-MERCKLING, D.; ROBBINS, L. B. Cardiorespiratory fitness as a mediator of the association between physical activity and overweight and obesity in adolescent girls. Childhood Obesity, v. 15, n. 5, p. 338-345, 1 jul. 2019.

WORLD MEDICAL ASSOCIATION, H. D. World Medical Association Declaration of Helsinki: Ethical Principles for Medical Research Involving Human Subjects. JAMA : the journal of the American Medical Association, v. 310, n. June 1964, p. 1-5, 2013.

Persp. Online: biol \& saúde, Campos dos Goytacazes, 39 (11) 37 - 57, 2021

ojs3.perspectivasonline.com.br 